\title{
POLITICS OF GENDER: A CRITICAL ANALYSIS OF SEX SEGREGATION IN NURSING PROFESSION
}

\author{
Dr. Ahammadu Zirajuddeen \\ Assistant prof. \& Head, Department of sociology, Institute of tribal studies \\ and research (ITSR), University of calicut, Calicut, Kerala
}

DOI: 10.46609/IJSSER.2020.v05i05.004 URL:https://doi.org/10.46609/IJSSER.2020.v05i05.004

\begin{abstract}
This paper explores sex segregation in nursing profession with an analysis of qualitative data from fieldwork conducted among male nurses in private and public hospitals in Delhi. Looking beyond the methodological binaries and conventional theoretical explanations of sex segregation such as individual role structure and social constructivism, this paper critically examines the actual ways in which the segregation is produced and reproduced. The paper focuses on individuals, micro situations, institutions and most importantly, the politico-economic structures and dominant ideologies of gender in producing the sex segregation. By putting forward empirical sources, I argue, sex segregation prevails in nursing field, it is not the product of individual role perception but a shared practice structured by both micro and macro social elements where power, business economy and politics are important variables.
\end{abstract}

Keywords: Sex segregation, Gender and occupation, Male nurse, Politics of Gender.

\section{INTRODUCTION}

In classical theoretical sense, one of the important patterns of division of labor in society is the social expectation of behavior and performance based on gender. In other words, it is termed as 'gendered division of labor' or 'gendered occupation'. Occupations get segregated when a large majority of workers belong to the same sex and when there is an associated normative expectation that this is how it should be (Merton, 1957, Quoted by Myron D.S, 1976). Nursing occupation has been one of the most sex typed occupation because of its congruence with the traditional female roles. In this paper, my attempt is to analyze sociologically how this phenomenon has been produced and reproduced by agents and structure in nursing profession. The paper tries to look beyond the idea of social expectation of behavior. Relying on the primary 


\section{International Journal of Social Science and Economic Research}

ISSN: $2455-8834$

Volume: 05, Issue: 05 "May 2020"

data, I argue, it is produced and reproduced by individual actors and larger social structures like medical market. The paper comes as a critical analysis of structural functional perspectives since individual no longer blindly conforms to the given social roles.

My paper looks beyond the conventional definitions of profession as a class-category which sees professionals as incumbents of certain roles and social functions, a set of objective attributes and subjective perceptions such as individual motivation, group interests and the system of stratification, static and unchangeable for the social equilibrium (Oommen, 1978, p.7, emphasis mine).

\section{Sex Segregation in Professions: an Overview of Studies}

Studies are galore on doctors and nurses in hospital setting especially in the context of American and European settings. T.K Oommen (1976), through his early work 'Doctors and Nurses: A study in the occupational Role Structure', emphasizes on occupational role commitment, perception of role, value orientation, role conflict, and role relations of doctors and nurses at the hospitals in Delhi. His work comes under the rubric of structural functional approach and sociology of profession. One of the main limitations of his work is, he did not mention on male nurses since he has conceptualized nursing profession as completely female, may be due to the then condition in 1960 s and 70 s.

Myron D Fottler (1978) had conducted a study in to the attitude of female nurses toward the male nurses based on occupational segregation. He says the vast majority of them have positive attitude toward male nurses and more should be encouraged to nursing where sex is an irrelevant factor. Bernard E Segal's study (1962) among the male nurses in the psychiatric department focuses on their status perception in contrast to their female colleagues inside and outside the hospital. He says male nurses have the low estimate of their self-esteem. Joan E. Manley (1995) located segregation in the historical process of nursing profession's inability to become a full profession. Liliane Floge and Deborah M Merril (1986), through their study on 'tokenism' of male nurses, hypothesized that the perceptual tendencies such as heightened visibility inside hospital help them positively for their occupational advancement.

\section{Fieldwork among Male Nurses in Delhi}

As I elaborated earlier, this paper explores how the actions of agents can be related to the larger contexts and how such contexts constitute the individual identities and actions and how actions produce and reproduce the these contexts, in other words, an empirical interlink between micro and macro methods. It looks beyond the antinomies of methodological holism, situationalism and individualism and takes a position where they are linked and interconnected rather than reduced 


\section{International Journal of Social Science and Economic Research}

ISSN: $2455-8834$

Volume: 05, Issue: 05 "May 2020"

and dichotomized. Thus, to find answers to my research questions, the empirical and theoretical dimensions of micro and macro should be brought together.

In this regard, Pierre Bourdieu $(1980,1992)$ has tried to bridge this methodological divisions between micro and macro, individual (subjectivist) and collective (objectivist) realms through his concept of habitus which explains the pattern of action and order (Bourdieu and Warcquant, 1992, p.20). According to him, individual subjectivity is produced through sharing a habitus, that is individual disposition rather than internalized normative order by which the practices and structures are produced and reproduced. Individual neither acts mechanically nor freely, rather, he is just like a football player who plays with his practical logic, rational strategies and calculations in order to fit to the soccer laws, that is 'fuzzy logic of practical sense' (ibid:19). Solving the methodological limitation of structuralism which fails to explain individual practicality and everyday life sociology which fails to analyze regularity and obligatory nature of action, Bourdieu identified habitus as pre-reflective collective cultural structure, implicit dispositions shared among participants in cultural practice with strategic relationships. Karin D. Knorr Cetina and Aron V Cicourel (1981) have also given similar approaches by reconstructing social theory and methodology towards micro and macro integration. But it differs from Bourdieu since they do not mention the reciprocal process of reproduction by the macro structures which seems appropriate for my arguments.

I have used purposive convenient snowball sampling method. My samples of study are male nurses working in public and private hospitals in Delhi. Male nurses were interviewed who are working in RML (Ram Manohar Lohia Hospital at Gole Market) and AIIMS (All India Institute of Medical Science), Batra private Hospital and Medical Research Centre in Tughlakkabad. These sites were the main epicenters of nurse's movement erupted in many parts of Delhi. All samples constitute the age group of 23 to 28 and all of them are from economically low background coming from Kerala. I have selected Delhi because the private nurses' exploitation and their movements happen in metropolitan cities. It was necessary to investigate in to the conditions of government hospitals to have a comprehensive idea, so, I selected both, private and government hospitals.

\section{Formation of professional identity}

Here, I examine the ways in which individual male nurse responds to and affected by his social involvements and typifications of profession. We also look into meaning making process and perceptions about his professional identity, and the behavioral dispositions according to the changing status of nursing profession as gender specific. The individual perception and identification have been influenced by the macro structures of norms and values which influence 
International Journal of Social Science and Economic Research

ISSN: $2455-8834$

Volume: 05, Issue: 05 "May 2020"

their 'professional everyday life'.

TABLE (1):

\begin{tabular}{|c|c|c|c|c|}
\hline Cases & $\begin{array}{l}\text { Their choice of } \\
\text { becoming a } \\
\text { nurse }\end{array}$ & Identity formation & $\begin{array}{l}\text { Individual's own } \\
\text { contribution towards } \\
\text { professional identity }\end{array}$ & $\begin{array}{l}\text { Socialization in } \\
\text { the past }\end{array}$ \\
\hline $\begin{array}{l}\text { Case (1) } \\
\text { RML }\end{array}$ & $\begin{array}{l}\text { Selected nursing } \\
\text { only because there } \\
\text { was a boom in } \\
\text { nursing job sector } \\
\text { during } 2005 \text { as APJ } \\
\text { Abdul Kalam } \\
\text { announced it in } \\
\text { parliament. }\end{array}$ & $\begin{array}{l}\text { The notion of nursing as } \\
\text { female profession is an old } \\
\text { concept, now it has turned } \\
\text { into a professional sector } \\
\text { even if he has personal } \\
\text { experience of discrimination } \\
\text { from Delhi. Was also } \\
\text { inspired by family and } \\
\text { friends. }\end{array}$ & $\begin{array}{l}\text { Male nurses are necessary in } \\
\text { hospitals because female } \\
\text { nurses cannot do everything } \\
\text { like taking patients to } \\
\text { different wards. Female } \\
\text { nurses have been tolerating } \\
\text { all problems without } \\
\text { responding, because they } \\
\text { cannot, only males can } \\
\text { initiate political actions } \\
\text { against exploitation. }\end{array}$ & \begin{tabular}{|l} 
Trained in Trivandrum \\
Medical college. It was \\
just like other \\
professional courses \\
without any gender \\
based r socialization. \\
But male admission is \\
less in number.
\end{tabular} \\
\hline $\begin{array}{l}\text { Case (2) } \\
\text { AIIMS }\end{array}$ & $\begin{array}{l}\text { Wanted to be doctor } \\
\text { but failed to get } \\
\text { admission, so, } \\
\text { selected a job with } \\
\text { assured placement as } \\
\text { APJ Abdul Kalam } \\
\text { announced about the } \\
\text { coming vacancies. }\end{array}$ & $\begin{array}{l}\text { Family members had } \\
\text { discouraged to select nursing } \\
\text { and still does not disclose to } \\
\text { them about the present status } \\
\text { in family functions. }\end{array}$ & $\begin{array}{l}\text { Girls would not participate } \\
\text { in Union activities. Student } \\
\text { politics started in nursing } \\
\text { sollege only after they } \\
\text { admitted boys. }\end{array}$ & $\begin{array}{l}\text { Before 2005, nursing } \\
\text { institutes were } \\
\text { Women's colleges. } \\
\text { Most of the office } \\
\text { bearers in the college } \\
\text { union were males and } \\
\text { the union started after } \\
\text { boys were admitted. }\end{array}$ \\
\hline \begin{tabular}{|l|} 
Case (3) \\
Batra Private \\
Hospital
\end{tabular} & $\begin{array}{l}\text { Compelled by } \\
\text { family to select it } \\
\text { due the job vacancy } \\
\text { and was not aware } \\
\text { of the problems with } \\
\text { nursing. }\end{array}$ & $\begin{array}{l}\text { Proud of doing a different } \\
\text { job that not all can do. } \\
\text { Experiencing status } \\
\text { inferiority from Delhi not } \\
\text { form Kerala because they } \\
\text { know about it. }\end{array}$ & $\begin{array}{l}\text { An idea about the unity and } \\
\text { an association for nurses } \\
\text { came up of only after males } \\
\text { have initiated it. Moreover, } \\
\text { Hospitals need male nurses } \\
\text { because females may not be } \\
\text { able to perform efficiently in } \\
\text { some departments as males } \\
\text { can. }\end{array}$ & $\begin{array}{l}\text { Training institute was a } \\
\text { professional one in } \\
\text { Karnataka demanding } \\
\text { high fees. There was } \\
\text { not gender-based } \\
\text { socialization. }\end{array}$ \\
\hline $\begin{array}{l}\text { Case (4) } \\
\text { Batra } \\
\text { Hospital }\end{array}$ & $\begin{array}{l}\text { Selected nursing due } \\
\text { to the job } \\
\text { opportunity in } \\
\text { abroad and was } \\
\text { service oriented. }\end{array}$ & $\begin{array}{l}\text { Parents had given whole } \\
\text { support. Thinks nursing is a } \\
\text { good profession but some of } \\
\text { the well-wishers started to } \\
\text { advice him to change to } \\
\text { other professions because }\end{array}$ & $\begin{array}{l}\text { Hospitals need them in some } \\
\text { particular departments such } \\
\text { as Ambulance services and } \\
\text { female nurses need their } \\
\text { support for their professional } \\
\text { well-being. }\end{array}$ & $\begin{array}{l}\text { Trained in Maharashtra } \\
\text { border, no experience } \\
\text { of gender } \\
\text { discrimination there. }\end{array}$ \\
\hline
\end{tabular}




\section{International Journal of Social Science and Economic Research}

ISSN: $2455-8834$

Volume: 05, Issue: 05 "May 2020"

\begin{tabular}{|c|c|c|c|c|}
\hline & & $\begin{array}{l}\text { the job opportunity has come } \\
\text { down, he regrets on his } \\
\text { career selection. }\end{array}$ & & \\
\hline $\begin{array}{l}\text { Case (5) } \\
\text { Male home } \\
\text { nurse }\end{array}$ & $\begin{array}{l}\text { At that time, the } \\
\text { scope for nursing } \\
\text { was high especially } \\
\text { in abroad which led } \\
\text { him take up nursing } \\
\text { profession. }\end{array}$ & $\begin{array}{l}\text { Family had no interest in his } \\
\text { career option. Job inferiority } \\
\text { is relative according to the } \\
\text { different areas such as } \\
\text { workplace in Delhi and } \\
\text { hometown in Kerala. They } \\
\text { do not know about the } \\
\text { difficulties in nurse training. }\end{array}$ & $\begin{array}{l}\text { Girls cannot work as home } \\
\text { nurse especially in cities like } \\
\text { Delhi due to the security } \\
\text { problem whereas boys are } \\
\text { ready to do 'anything'. } \\
\text { Female nurses have been } \\
\text { tolerating all kinds of } \\
\text { exploitation unlike male } \\
\text { nurses, they only 'respond' }\end{array}$ & $\begin{array}{l}\text { During his training, } \\
\text { there were more boys } \\
\text { but now boys are less } \\
\text { in number. He felt } \\
\text { nursing college as just } \\
\text { a professional institute. }\end{array}$ \\
\hline
\end{tabular}

The table shows that opting nursing profession is an instrumental rational action (see first column on reason behind the selection) not because 'psychological problem of femininity' or 'homo' character as some authors have identified (cf. Floge L and Merril D, 1986). Rather, it is all about career preference through the conditioning character of cultural habitus which governs the ways individuals adopt for their success. Male nurses are not the passive recipients of social constraints regarding the selection of a non-traditional job so that it cannot not be taken as the prime source of the production of sex segregation in their profession.

We see male nurses inculcate and appropriate the social structures into their life according to the market economy of nursing profession. Most of them are not feeling status inferiority which has an inherent relation to other factors such as context and family, which seems contrasting to the findings of Bernard E. Segal (1962) and T K Oommen (1978, p. 61).

Individual habitus, structured in this way, produce the phenomena of sex segregation as I have stated (see column on attitude towards female nurses). All of my male informants 'think' that female nurses cannot respond and react against the forms of exploitation and they were physically and mentally 'unfit' to assert their rights. According to them, female nurses want to continue their job 'anyhow' because their earning is the sole source of income for their natal or conjugal family unlike males who are the prime income source for their family and they experience more pressure. Even if the initiation to the 'female profession' is solely because of their economic interests, the structures inside the profession have been conditioned by the meaning of gender stereotypes and male nurses are part of it.

Primary socialization agencies like family and peer group have an important role in producing the typification of each individual (see column on subjective embodiment) as they are conditioned by existing norms of their own particular society. As I could experience from my childhood, the 'sex typing' is less among south Kerala society unlike that of north Kerala and 
religion is also very important in the structuring of agencies (it was mentioned by Oommen $\mathrm{T} \mathrm{K}$, 1978, p. viii-ix). While Christians enter into the field in large number, Hindus hesitate whereas Muslims show little interest in it, which is not my main concern in this paper. However, my argument is, the macro contexts of norms and values define the individual disposition of sex segregation in a relative manner (see rows $2,4,6$ in table). It is not at all because of the homogeneous and inherent natural sex role perception and the individual typification of the taken for granted worldviews. Subjective perceptions about the role of 'nurse' and the formation of professional identity are rather more affected by the organizational constraints than the gendered identity of the nursing profession.

\section{Practice of Sex segregation in micro situations}

The dynamics of interactions and daily life in the hospital setting represent the practice of sex segregation in professions. Just as the micro level interactions and communications between groups are produced by the larger contexts of politics and embodiment of professional identity, it reproduces those structures also. In this section, I look what they do in hospitals, to which departments they have been more allocated, patterns of interaction among different occupational groups such as doctors and administrative staffs and the intended and unintended objective facts it produce.

TABLE (2):

\begin{tabular}{|c|c|c|c|}
\hline Cases & $\begin{array}{l}\text { Production of gender } \\
\text { typification via Division } \\
\text { of Labor }\end{array}$ & $\begin{array}{l}\text { Gender identity and } \\
\text { everyday life in work } \\
\text { setting }\end{array}$ & $\begin{array}{l}\text { Professional role } \\
\text { commitment }\end{array}$ \\
\hline RML Govt. Hospital & $\begin{array}{l}\text { He has been working in } \\
\text { Coronary Care Unit (CCU). } \\
\text { Males are absent in } \\
\text { gynecology department while } \\
\text { they are assigned more in } \\
\text { operation theaters }\end{array}$ & $\begin{array}{l}\text { Though the instances of } \\
\text { gender discrimination are rare, } \\
\text { there is gendered division of } \\
\text { labor inside hospital but it is } \\
\text { not visible in government } \\
\text { hospitals }\end{array}$ & $\begin{array}{l}\text { He is interested to attend } \\
\text { 'rare' cases to study about } \\
\text { it. He has curiosity to know } \\
\text { more. }\end{array}$ \\
\hline AIIMS Govt. Hospital & $\begin{array}{l}\text { He works in D2 medical ward. } \\
\text { There is female domination in } \\
\text { other departments. }\end{array}$ & $\begin{array}{l}\text { He has faced many problems } \\
\text { due to his gender especially } \\
\text { when treating female patients } \\
\text { like taking ECG. Now it is a } \\
\text { friendly relation with male and } \\
\text { female colleagues. }\end{array}$ & $\begin{array}{l}\text { In Kerala, he could see } \\
\text { 'some' case only such as } \\
\text { surgical but in AIIMS there } \\
\text { are many 'unheard' cases. } \\
\text { Main concern is salary. }\end{array}$ \\
\hline Batra Private Hospital(1) & $\begin{array}{l}\text { He works with emergency } \\
\text { cases in ICU. }\end{array}$ & $\begin{array}{l}\text { Male nurses have been } \\
\text { allocated male patients only } \\
\text { unlike female nurses who are } \\
\text { supposed to attend both male }\end{array}$ & $\begin{array}{l}\text { Nurses have more } \\
\text { commitment towards } \\
\text { patients since they spend } \\
\text { more time with them than }\end{array}$ \\
\hline
\end{tabular}




\section{International Journal of Social Science and Economic Research}

ISSN: $2455-8834$

Volume: 05, Issue: 05 "May 2020"

\begin{tabular}{|l|l|l|l|} 
& & $\begin{array}{l}\text { and female patients. Never } \\
\text { workex except in emergency } \\
\text { ICU }\end{array}$ & $\begin{array}{l}\text { doctors. Interested to learn } \\
\text { more about cases. }\end{array}$ \\
\hline Batra Private Hospital(2) & $\begin{array}{l}\text { He works in Cardiac unit and } \\
\text { Ambulance service where } \\
\text { males dominate }\end{array}$ & $\begin{array}{l}\text { Keeps good relation with } \\
\text { female colleagues and doctors. }\end{array}$ & $\begin{array}{l}\text { Since he is service oriented, } \\
\text { he shows humanity even if } \\
\text { he is not in duty. Has } \\
\text { curiosity to get more } \\
\text { information about cases. }\end{array}$ \\
\hline Home nurse & $\begin{array}{l}\text { Caring a rich patient, giving } \\
\text { food, medicine, looking sugar } \\
\text { level etc.. }\end{array}$ & $\begin{array}{l}\text { Has experienced some patients } \\
\text { prefer female nurses whereas to leave after duty } \\
\text { some doctors prefer male } \\
\text { nurses because of their } \\
\text { efficiency. }\end{array}$ & $\begin{array}{l}\text { having no anxiety to learn } \\
\text { interesting cases'. }\end{array}$ \\
\hline
\end{tabular}

We see that micro situations can influence the individual dispositions and institutional positions. An overview of the placement of nurses in different departments creates an impression that just as women are denied some 'technical jobs' in work sphere (Fernandes, 1997, p.58-88), male and female nurses are concentrated in some 'appropriate departments' which produce gendered everyday practices that reproduce gendered hierarchies and exclusion. This process of naturalization of division of labor generates and reinforces the masculinity associated with some mechanical jobs and femininity with patience and dedication to repetitive tasks as it defined by the gendered subjective embodiment (table. 1) and the political economy of gender as I would explain it in the last section.

My findings with regard to the micro interactions in daily life in hospital setting unfolds different tendencies unlike theoretical propositions of symbolic Interactionism and exchange theories which hold, in situations in which persons of one social type are extreme minority are expected to have specific behaviors (Floge. L and Merril D M, 1986). In our case, male nurses experience heightened visibility, that is, they are more visible than their female colleagues due to the surveillance of their actions by hospital administration especially after their political movement. Their names, aspects of personal life, mistakes in workplace have been highly noticed than that of female nurses because they are seen as the 'trouble making nursing leaders', so that they can be suspended or terminated easily.

Column No.4 denotes the organizational constraints on nurses in hospital setting are not due to the lower professional autonomy and lack of prestige and it does not lead them to bureaucratization as Oommen had identified (1978, p.122). Arun (Home nurse who had worked in a private hospital) says: 


\section{International Journal of Social Science and Economic Research}

ISSN: $2455-8834$

Volume: 05, Issue: 05 "May 2020"

"How can a nurse, who is compelled to work for 10 hours continuously on 1:10 nurse patient ratio, have humanitarianism and professional curiosity to attend more cases instead of going home and take rest? If they give us adequate salary, proper shifting of duty, at least 1:3 nurse patient ratio, definitely we would become more professional than doctors".

My point is, low professionalism does not promote bureaucratization, so that, nurses are also professionals in that sense. Low professionalism and less autonomy are not the real causes behind their subordination to administration or professional doctors. Instead, they are controlled by bureaucratic administration in order to exploit them that produce 'sex types' of a non-rational non-responsive 'altruistic' labors, for which girls are seen comparatively appropriate.

Here we can find out the discrepancies between the normative aspects of role expectation and the actual conduct of male nurses. Their professional role commitment does not mean a consistent pattern of behavior but a changing attitude according to changing situations as they stroked for their demands. This view is in contrast with what Oommen said "nurses find it easier to combine both bureaucratic and collectivistic orientations, also they seem to view organization constraints as natural and do not rebel against these being semi-professionals" (ibid: 125, emphasis mine).

\section{Production of Institutional positions}

TABLE (3):

\begin{tabular}{|l|l|l|l|}
\hline & Entry cadre & Mode of promotion & Gendered symbols \\
\hline Nursing institutes & $\begin{array}{l}\text { Entry for males is severely } \\
\text { discouraged }\end{array}$ & $\begin{array}{l}\text { Some posts are exclusively } \\
\text { restricted for females such as } \\
\text { tutor whereas the most of the } \\
\text { union leaders are males. }\end{array}$ & $\begin{array}{l}\text { No union activities are } \\
\text { allowed until boys came } \\
\text { and admission to boys } \\
\text { restricted soon after thy } \\
\text { started political agitations. }\end{array}$ \\
\hline $\begin{array}{l}\text { Government Hospitals } \\
\text { and training colleges }\end{array}$ & $\begin{array}{l}\text { Even if gender discrimination } \\
\text { is not visible inside it, it is } \\
\text { very difficult for males to } \\
\text { enter into nursing post. }\end{array}$ & $\begin{array}{l}\text { Higher posts above staff nurse } \\
\text { are female such as ANS, DNS, } \\
\text { NS, even though criteria of } \\
\text { known as 'sister in- } \\
\text { phomarge'. And Some } \\
\text { not educational qualifications. } \\
\text { departments such as } \\
\text { Pediatry and gynecology } \\
\text { are exclusively female } \\
\text { dominated }\end{array}$ \\
\hline Private Hospitals & $\begin{array}{l}\text { Percentage of recruitment for } \\
\text { males is more dismal than } \\
\text { govt. hospitals. }\end{array}$ & $\begin{array}{l}\text { No males in superior staffs } \\
\text { such as In-charge of Dept., } \\
\text { ward supervisor and Head of } \\
\text { Dept. }\end{array}$ & $\begin{array}{l}\text { Some departments such as } \\
\text { Pediatry and gynecology } \\
\text { are exclusively female } \\
\text { dominated. }\end{array}$ \\
\hline Home Nursing & Female nurses are denied & No promotion there & The word 'home nurse' \\
\hline
\end{tabular}




\section{International Journal of Social Science and Economic Research}

ISSN: $2455-8834$

Volume: 05, Issue: 05 "May 2020"

\begin{tabular}{|l|l|l|l|} 
& $\begin{array}{l}\text { recruitment due to the security } \\
\text { problems. }\end{array}$ & & $\begin{array}{l}\text { denote for them as } \\
\text { domesticated female. }\end{array}$ \\
\hline Military Nursing & $\begin{array}{l}\text { No recruitment for male } \\
\text { nurses }\end{array}$ & On the basis of seniority & $\begin{array}{l}\text { Nursing post itself means } \\
\text { female nursing post. }\end{array}$ \\
\hline Foreign Recruitment & $\begin{array}{l}\text { Every foreign county } \\
\text { and Emigration }\end{array}$ & $\begin{array}{l}\text { Pecruitment agencies prefer } \\
\text { females as they get directions } \\
\text { from hospitals there. Some } \\
\text { countries like Saudi Arabia do is according to } \\
\text { experience rather than } \\
\text { knowledge. There is high } \\
\text { preference for female nurses at males at all. }\end{array}$ & $\begin{array}{l}\text { High percentage of } \\
\text { sending girls to nursing } \\
\text { colleges is aimed at } \\
\text { international level. }\end{array}$ \\
\hline
\end{tabular}

Here I attempt to answer various underlying questions hidden under the general term 'role expectation' or 'given structural roles'. What are the real causes behind the chronic exploitation of nurses by the private hospital management? Why their protests have been suppressed? Is it due to their professional less autonomy? Why male nurses are not admitted in nursing colleges, especially in government colleges? Why the posts of nursing profession are known as gendered symbol such as 'sister grade 2'? Why nurses have been promoted only on the basis of experiences not according to their degrees and training qualification? Why male nurses are not preferred for the recruitment to the hospitals in foreign countries (especially US, Europe, Australia, GCC countries)? Statement of those structural causes behind this would, I think, unravel the history of hegemony and economic exploitation and the chronic economic deprivation of nurses in India. An attempt to answer those questions would explain how sex segregation is produced in nursing profession.

As my informants told me, they have are not paid even 10 per cent of what patients pay for their nursing service. Therefore, 99 per cent of money which has been collected on their name by private hospitals is accumulated by hospitals as 'wage profit'. From my group interaction with male nurses, I could find out there is not a single hospital in Delhi which runs in loss but all problems would get solved if they spare a 'a little amount' of their profit to nurses since it is their right.

According to our informants, some nursing aspirants who complete their courses from Maharashtra and Karnataka may not have professional quality since they get certificate without attending classes. After completing the course, they pay hospitals for appointing them as nurses to learn and have experience in order to go abroad. Thus, the hospital management becomes happy to keep them even if they have no quality since they can be paid very less without any demand for salary hike. Likewise, the institutions regarding the nursing profession have been typified with an assumption that female nurses would not 'respond' to all these forms of 


\section{International Journal of Social Science and Economic Research}

ISSN: $2455-8834$

Volume: 05, Issue: 05 "May 2020"

exploitation since decades (Oommen's study in 1976 would reveal the high percentage of female nurses in Delhi and their dismal salary but hospitals never experienced a strike until 2011). According to the hospital management, females are easily 'manageable' and 'unresponsive' to any situation. One of the officials said that as long as Kerela Express and Mangla Express trains come from Kerala daily, we are not concerned about the scarcity of nurses. So that we can easily suspend the 'problem creating nurses' who demands salary hike.

I think, it is due to this reason of accumulation of capital through perpetuation of gender typification and exploitation of labors on gender lines that males are not admitted and promoted to higher posts. As one of my informants told me, it is very rare a male reaches higher posts in nursing hierarchy such as $\mathrm{AN}$ or DN by promotion through experience, because he cannot survive to that much time unlike females. In Batra hospital, only female nurses have access to hostel facility whereas males have to find out their residence on their own risk. This section and the following theme have to be read in relation with each other since both are inseparable and interconnected to understand the phenomena of 'sex typing' in nursing profession.

As Marie Percot and Irudaya Rajan (2007) have identified, out of 17 percent of female Emigration from Kerala, Christian emigrants include 32 percent and most of them are nurses in Gulf and Western countries. Their migration has increased by 144 per cent between 1999 and 2004. Foreign recruitment agencies always prefer female nurses especially after the movement which has been exploited by their own families and hospitals. Matrimonies sites of Malayalam newspapers show the trend of 'nurse working in Europe'. Her natal family benefits from her wage, by sending money, helping another member to emigrate and after marriage, in law family members can emigrate with her help, which is not possible in male nurses' case.

\section{Politics of Gender in Working place}

The politics of categories at macro level produces the social identities and practices which get unfolded through the individual perception and everyday experiences. In this section, I examine how the politico-economic processes at institutional level such as the business organizational structure of private hospitals shape the sex segregation in nursing profession which are reproduced by the gendered actions individuals agents. The political actions of nurses as a professional group are represented by the male dominated leadership, which creates a masculine symbol of 'leader' in the institutions through the 'gendered disposition' of the male nurses. Let us examine how the politics of gender has been produced by the agents (male nurses) themselves through the prevailing social norms regarding the notion of gender based division of labor.

One of my informants (Mujeeb working in AIIMS) recollects his experiences about his training period: 


\section{International Journal of Social Science and Economic Research}

ISSN: $2455-8834$

Volume: 05, Issue: 05 "May 2020"

"When I was undergoing my training period in Kerala, political activities was strictly prohibited and I was an activist of SFI (Student Federation of India). However, soon after boys started to take admission into nursing colleges during the boom years of 20042007, a nursing college union was formed. Nursing college got an 'exposure' thanks to boys. I worked as the editor of college magazine. In my batch (2007-2008), all of the office bearers in union were boys. Therefore, at the starting of my second year, college authorities thought that, boys were completely responsible for all 'problems'. In most of the political sessions, the decision of boys dominated over girls in a college dominated by girls. The problem with girls is they will not initiate any political action. For instance, in 2005, female nurses protested in one hospital in Kerala. They got a warning of dismissal if they failed to attend their duty within 15 minutes. What happened is that, they followed the administration and continued their duty without any agitation. If boys were in their place, that protest would have been a success".

We see here an overlapping between politics of gender and politics of class produced by the agencies which in turn reproduced by institutions. Exclusionary representation of gender identity at institutional and micro levels in nursing profession in private and public hospitals produce segregation between groups of professionals which maintain the relations of domination and subordination, in other words, perpetuate the gender oppression. It is through this reciprocal process that I analyze the categorical distinction between male and female nursing professionals in India.

From the personal accounts of a 'victim' of the gendered political process below, I point to the ways $n$ which the sex segregation in the nursing profession has been reproduced by the larger institution of hospital under the ambit of political movements of nurses.

One of my informants (who works as the general secretary of DPNA) told me:

"It was in May 2010 that we thought about an association for nurses and conducting a strike to get our demands met. We had send letters to chief minister, hospital management and kept them informed about our strike before two months. When there was not a single positive response from the hospital administration, we started strike in front of Batra hospital; it was first of its kind in nursing history in India. Within 7 days, a solution formula was formed, which says, the bond system would be stopped, salary will increase, nurses will get the protection of health insurance. Then we stopped strike. Soon after the strike, I was suspended, and later, they terminated me. I think they have unity among the authorities of private hospitals in Delhi, so all private hospitals have stopped recruiting male nurses. Protest marches are watched by them. They have suspended some 


\section{International Journal of Social Science and Economic Research}

ISSN: $2455-8834$

Volume: 05, Issue: 05 "May 2020"

female nurses also who have participated in protest but they have been taken back into service. But the suspended male nurses never have been taken back.

As Leela Fernandes (1997) has identified, I could see some shifts from the sociological conceptualization of class and gender in those movements. Category of gender becomes central at this political context rather than that of class even they interact with each other in actual situations. The conceptualization of class has to be juxtaposed to the cultural identity of gender that seems an analytical category to explain the politics of gender in nursing profession as 'structured and contested category of class'. Thus, the social category of gender has been constructed according to the symbolic image and the identity of class is challenged by other identity, (here it is gender), deconstructing a homogeneous universalistic categories of class in certain situations. It seems contrary to the Marxian notion of class where the cultural and other social features are outside of the unifying category of class.

Putting forward the narratives of political actors in nurses' movements I would argue, this is a shift from the class-based movements to the formation of complex relationship of gender and class. From my empirical data, I could find that the ways of asserting the professional prestige and demands, formation of occupational pressure groups in the nursing profession have been conditioned by the social identity of gender failing to form a unitary crystallization of class interests. It involves a continuing negotiation of power and hegemony through individual, discursive and everyday social discourses based on gender identity. As Bourdieu and Warcquant (1992, p.17-18) has identified, it is a space of conflict and competition like a battlefield in which participants try to establish monopoly over the 'species' of capital appropriate to that field.

Vishnu (one of informants from Batra Hospital) told me:

"After the nurse movements, you can see large scale dropout of male nurses from private hospitals and the percentage of male admission to nursing profession has decreased. Because, after the movement, management increased salary for juniors who have been admitted on 'contract' basis whereas the 'permanent seniors' are facing salary cut. According to them, seniors would 'respond' unlike juniors who are 'purchased labor'. Some of us are changing to any other profession. We don't have any advantage out of the label 'permanent' whereas hospital has the legal authority to dismiss contract based nurses at any time they want, so, contracted juniors will not respond and participate in any strike".

Jacob (working as senior staff, aged 34 in surgery ward) says:

"I had a good relation with our Head of Dept. who was one of the owners of hospital. 
International Journal of Social Science and Economic Research

ISSN: $2455-8834$

Volume: 05, Issue: 05 "May 2020"

However, after I worked in the forefront of movement, our mutual relation worsened. Nursing Superintendent kept a distance from me unlike before. She has been forced to do that since she is unable to get another job in this age. Now HoD looks me with 'revengeful' mind. He becomes angry even seeing me. We got support only from doctors. And there were effort to divide us on the basis of gender, but we stood firm until success".

Suffice is to say that, the whole political processes by agents and structure get amalgamated in the formation of an 'ideal nurse' on the gender lines. It has been analyzed under the context of nurses' movement in Delhi which has redefined their identity in the working place. I have used here the material and economic base, actual power structure to analyze the occupational role of male nurse in non-traditional job sector in contrast to the functional variables used by $\mathrm{T}$. K Oommen (1978).

\section{CONCLUSION}

Throughout this report, I have tried to give an alternative perspective to study the phenomena of sex segregation in professions taking an empirical example of male nurses in Delhi. According to this perspective, individuals are not passive recipients of social role structures and behavioral expectations, rather, they produce phenomena such as sex segregation conditioned by macro contexts such as political economy which in turn reproduce those individual actions. Hence, I argue, in order to understand the sex segregation in professions such as nursing, we may have to think beyond the conventional categories like gender role or behavioral expectation and focus on how segregation is produced by the larger institutions like profit based medical market and the actions, practices, and socialization of individuals at micro level.

\section{BIBLIOGRAPHY}

Cetina. Knorr (1981) 'Introduction: The micro-sociological challenge of macro-sociology: towards a reconstruction of social theory and methodology' in Cetina and A.V Cicourel (Ed.) Advances in Social Theory and Methodology. London: Routledge

Bourdieu, Pierre and Wquant J.D (1992). An invitation to Reflexive Sociology. Cambridge: Polity Press

Bohman. James (1991) New Philosophy of Social Science: Problems of Indeterminacy. Cambridge: Polity Press 
International Journal of Social Science and Economic Research

ISSN: 2455-8834

Volume: 05, Issue: 05 "May 2020"

Denny E, Earle Sarah (2005). Sociology for nurses. Cambridge: Polity Press

Dey. Ian (1993). Qualitative Data Analysis: A User-friendly guide for Social Scientists. London: Routledge

Fernandes. Leela (1997) Producing workers: The Politics of Gender, Class, and Culture in the Calcutta Jute Mills. New Delhi: Vistar Publications

Floge L and Merill. Barbarah M (1986) 'Tokenism Reconsidered: Male nurses and Female physicians in a hospital setting', Social Forces, Vol. 64, No.2, pp. 925-947, OUP

Graham Gibbs (2007) Analyzing Qualitative Data, from 'The SAGE Qualitative Research Kit' (Edited By Uwe Flick). Sage: London

Joel E, Heicks(1991) 'When men are minority: The case of men in nursing', Sociological Quarterly, Vol.32, No.3, pp.384-401, Blackwell

Manley, Joan (1995) 'Sex segregated work in the system of profession, the development and stratification of Nursing, The sociological Quarterly, Vol.36, No.4, pp.297-314, Blackwell

Oommen, T K (1978) Doctors and Nurses: A study in Occupational Role Structures. Delhi: Macmillan

Percot, Marie, Rajan S. Irudaya (2007) Female Emigration form India: Case Study of Nurses, $E P W$, pp. $318-325$

Silverman. David and Marvast. Amir (2008) Doing Qualitative Research: A Comprehensive Guide. London: Sage

Strauss. A.L (1987) Qualitative Analysis for Social Scientists. Cambridge: Cambridge University Press

Wharton, Amy S (2012) The Sociology of gender: An introduction to Theory and Research. UK: Willey Blackwell 